\title{
Correction to: Biomonitoring of Toxic Metals in Feathers of Birds from North-Eastern Pakistan
}

\author{
Bushra Rashid $^{1} \cdot$ Muhammad Zubair $^{2} \cdot$ Nausheen Irshad $^{1} \cdot$ Khawaja Shafique Ahmad $^{3} \cdot$ Majid Mahmood $^{1}$. \\ Majid Mahmood Tahir ${ }^{4} \cdot$ Khizar Hussain Shah $^{5} \cdot$ Aqeela Shaheen ${ }^{4}$
}

Accepted: 28 March 2021

(c) The Author(s) 2021

\section{Correction to: \\ Bulletin of Environmental Contamination and Toxicology https://doi.org/10.1007/s00128-021-03184-w}

The original version of the article unfortunately contained a mistake in second name of first author. The correct name of first author was Bushra Rashid. This has been corrected with this erratum.

Open Access This article is licensed under a Creative Commons Attribution-NonCommercial-NoDerivatives 4.0 International License, which permits any non-commercial use, sharing, distribution and reproduction in any medium or format, as long as you give appropriate credit to the original author(s) and the source, and provide a link to the Creative Commons licence. You do not have permission under this licence to share adapted material derived from this article or parts of it. The images or other third party material in this article are included in the article's Creative Commons licence, unless indicated otherwise in a credit line to the material. If material is not included in the article's Creative Commons licence and your intended use is not permitted by statutory regulation or exceeds the permitted use, you will need to obtain permission directly from the copyright holder. To view a copy of this licence, visit http://creativecommons.org/licenses/by-nc-nd/4.0/.

Publisher's Note Springer Nature remains neutral with regard to jurisdictional claims in published maps and institutional affiliations.

The original article can be found online at https://doi.org/10.1007/ s00128-021-03184-w.

Muhammad Zubair

drzubairabbasi@gmail.com

1 Department of Zoology, University of Poonch Rawalakot (UPR), Rawalakot 12350, Azad Jammu and Kashmir, Pakistan

2 Department of Veterinary Clinical Sciences, University of Poonch Rawalakot, Rawalakot, Azad Jammu and Kashmir, Pakistan

3 Department of Botany, University of Poonch Rawalakot (UPR), Rawalakot 12350, Azad Jammu and Kashmir, Pakistan

4 Department of Soil and Environmental Science, University of Poonch Rawalakot (UPR), Rawalakot 12350, Azad Jammu and Kashmir, Pakistan

5 Department of Chemistry, Comsats University Islamabad, Abbottabad Campus, Abbottabad, KPK, Pakistan 